Original Research Paper

\title{
High Level of Nicotianamine Synthase (NAS3) and Natural Resistance Associated Macrophage Protein (NRAMP4) Gene Transcription Induced by Potassium Nitrate in Trembling Aspen (Populus tremuloides)
}

\author{
${ }^{2}$ Karolina M. Czajka and ${ }^{1,2}$ Kabwe Nkongolo \\ ${ }^{1}$ Biomolecular Sciences Program, \\ ${ }^{2}$ Department of Biology, \\ Laurentian University, Sudbury, Ontario, Canada, P3E 2C6, Canada
}

Article history

Received: 27-01-2018

Revised: 26-02-2018

Accepted: 10-07-2018

\section{Corresponding Author:}

Kabwe Nkongolo

Biomolecular Sciences Program and Department of Biology,

Laurentian University,

Sudbury, Ontario, Canada, P3E

2C6, Canada

Email: knkongolo@laurentian.ca

\begin{abstract}
Changes in gene transcription in response to excess metal concentrations have been reported in many organisms, including yeast, microorganisms and plants. Most investigations on the effects of nickel toxicity in plants use commercial salts whose effects have not been analyzed in detail. The main objective of the present study was to determine the effects of different doses of nickel nitrate and potassium nitrates on gene transcription in Populus tremuloides. Four month-old $P$. tremuloides seedlings were treated with different doses of nitrate salts including $150 \mathrm{mg} / \mathrm{kg}, 500 \mathrm{mg} / \mathrm{kg}, 800 \mathrm{mg} / \mathrm{kg}$ and $1,600 \mathrm{mg} / \mathrm{kg}$. A significant increase of Nicotianamine Synthase (NAS3) gene transcription was induced by the $400 \mathrm{mg} / \mathrm{kg}$ and $800 \mathrm{mg} / \mathrm{kg}$ of nickel nitrate doses compared to water. This upregulation was driven by nitrate rather than nickel. Likewise, the $800 \mathrm{mg} / \mathrm{kg}$ and $1,600 \mathrm{mg} / \mathrm{kg}$ doses of potassium nitrate resulted in significant increase in the transcription of Natural Resistance Associated Macrophage Protein (NRAMP4) gene compared to water control and the $150 \mathrm{mg} / \mathrm{kg}$ dose. This differential transcription of this gene was caused by potassium. Our results also confirmed that the low level of bioavailable nickel in metalcontaminated soils $(<150 \quad \mathrm{mg} / \mathrm{kg})$ cannot induce differential transcription of NAS3 and NRAMP4. The use of nitrate without nickel should be required as additional controls in any study assessing effects of $\mathrm{Ni}$ using nickel nitrate salts.
\end{abstract}

Keywords: Trembling Aspen (Populus temuloides), Gene Transcription, Nickel Toxicity, Nickel Nitrate, Potassium Nitrate, RT-qPCR

\section{Introduction}

Nickel is a micronutrient required for plant growth and physiological functions. An excess amount will cause $\mathrm{Ni}$ toxicity that is detrimental to plant development. With the increasing levels of $\mathrm{Ni}$ contamination in the environment, it is essential to understand the functional roles and toxic effects of $\mathrm{Ni}$ in plants. Changes in gene transcription in response to excess metal concentrations are commonly seen in metal tolerant plants like hyperaccumulators. Genes that have been identified to possibly play a role in metal tolerance in plants can be species-specific and metal-specific. Recent reports showed that Populus tremuloides is a metal accumulator species. It grows readily in sites contaminated with a high content of $\mathrm{Ni}$ in Northern Ontario (Canada) (Mehes-Smith et al., 2013). This species does translocate excess $\mathrm{Ni}$ and zinc $(\mathrm{Zn})$ from roots to leaves. Metal accumulator plants such as $P$. tremuloides use genes that have a similar function and are commonly involved in metal transport (Kalubi et al., 2016).

A recent review of literature revealed 11 genes associated with nickel resistance in model and non-model plants. These genes include 1-Aminocyclopropane-1- 
Carboxylic acid deaminase (ACC), high affinity nickel transporter family protein (AT2G16800), Iron-Regulated protein (IREG), Glutathione Reductase (GR), glutathione-s-transferase, Metal Transporter (NRAMP 1,2,3,4), Nicotianamine Synthase (NAS3), Putative Transmembrane Protein (TMP), Serine acetyltransferase (SAT), Thioredoxin family protein, Zn finger protein of Arabidopsis thaliana (ZAT11) and MRP4 (Freeman et al., 2004; Lemaire et al., 2004; Stearns et al., 2005; Mizuno et al., 2005; Schaaf et al., 2006; Mari et al., 2006; Visioli et al., 2012; Liu et al., 2014; Theriault et al., 2016a). NAS3 and NRAMP 4 are associated with $\mathrm{Ni}$ transport and are well studied in many microorganisms and plant species. Information on their transcription under metal stress in tree species is very limited.

The Natural Resistance Associated Macrophage Protein (NRAMP) transporter is a family of genes whose main function is to bind and transport divalent metal ions. This is a highly conserved gene family during evolution and homologues have been identified in a large range of organisms including bacteria, yeast, mammals and higher plants (Williams et al., 2000).

The Nicotianamine Synthases genes (NAS1, 3 and 4) on the other hand, are a group of enzymes that synthesize the metal chelator Nicotianamine (NA). This nonproteinogenic amino acid can bind to some transition metals like $\mathrm{Fe}, \mathrm{Cu}, \mathrm{Zn}, \mathrm{Mn}$ and $\mathrm{Ni}$ and immobilize them for transport. NA has already been implicated in transporting $\mathrm{Fe}, \mathrm{Cu}$ and $\mathrm{Zn}$ for long distances within plants (Wintz et al., 2003).

It should be pointed out that most studies using nickel nitrate as salts to study the effect of $\mathrm{Ni}$ on gene transcription ignore the potential effects caused by these nitrate anions (Freeman et al., 2004; Douchkov et al., 2005; Merlot et al., 2014). However, there is evidence that high nitrate concentrations can be phytotoxic when they exceed the thresholds that plants can tolerate (Parker et al., 1983; Goyal and Huffaker, 1984). We hypothesize that both nickel and nitrate at high concentrations can trigger an increase of $N A S$ (1, 3 and 4) and NRAMP transcription in plants and that potassium will have no effects on these genes.

The main objectives of the present research were to determine the effects of different doses of nickel nitrate and potassium nitrates on gene transcription in P. tremuloides.

\section{Materials and Methods}

\section{Nickel Toxicity Assessment}

Populus tremuloides seeds were provided by the Canadian Forest Services seed bank (Fredericton). These seeds were collected in Woodstock, NB (seedlot\# 20061003.0) and stored at $4^{\circ} \mathrm{C}$. Seeds were germinated in "Petawawa" germination boxes and seedlings were grown in a deep tray with soil. Four month-old seedlings were transplanted into pots containing a 50:50 sand/soil mixture and left to grow for an additional month and a half in a growth chamber. Plants were watered as needed and fertilized twice a week with equal amounts of nitrogen, phosphorus and potassium (20-20-20).

$\mathrm{Ni}$ toxicity was assessed by treating seedlings with an aqueous solution of nickel nitrate salt $\left[\mathrm{Ni}\left(\mathrm{NO}_{3}\right)_{2}\right]$ at the following concentrations: $150 \mathrm{mg}, 400 \mathrm{mg}, 800 \mathrm{mg}$ and 1,600 $\mathrm{mg}$ of nickel per $1 \mathrm{~kg}$ of dry soil. To control for any possible toxic effect due to an increase in nitrate ions $\left(\mathrm{NO}_{3}\right)$ in the plants, an aqueous solution of commercial potassium nitrate $\left(\mathrm{KNO}_{3}\right)$ salts was used for controls in equal molar amounts to each dose of the nickel salts. The nitrate controls for $1,600 \mathrm{mg} / \mathrm{kg}, 800$ $\mathrm{mg} / \mathrm{kg}, 400 \mathrm{mg} / \mathrm{kg}$ and $150 \mathrm{mg} / \mathrm{kg}$ corresponds to $603.38 \mu \mathrm{mol}, 301.69 \mu \mathrm{mol}, 150.85 \mu \mathrm{mol}$ and 113.08 $\mu \mathrm{mol}$ of nitrate respectively. Salt-free water was used as a negative control ( $0 \mathrm{mg} \mathrm{Ni}$ per $1 \mathrm{~kg}$ of dry soil). The experimental layout was a completely randomized block design with 12 replications per each nickel treatment, 11 for the water control and 5 per nitrate control. Roots were harvested from seedlings after 7 days of treatments, frozen in liquid nitrogen and stored at $-20^{\circ} \mathrm{C}$ for RNA extraction.

\section{$R N A$ Extraction and RT-qPCR}

Total RNA was extracted from the root samples using the protocol described previously by Theriault et al. (2016b) with some modifications. Only $0.3 \mathrm{~g}$ of root material were used to extract RNA. The chloroform phase separation steps were carried out with $1 \mathrm{ml}$ of CTAB solution: $1 \mathrm{~mL}$ phenol chloroform. RNA was precipitated in $100 \mu \mathrm{L}$ of SDS extraction buffer and chloroform steps were scaled down accordingly. Extracted RNA from 49 samples was run on a $1 \%$ agarose gel to verify quality. It was quantified with the Qubit ${ }^{\circledR}$ RNA BR assay kit by Life Technologies (Carlsbad, United States). Samples from the same treatment were pooled together in equal amounts resulting in a total amount of 10 micrograms of root RNA per treatment.

Pooled RNAs were treated with DNase 1 (\#EN0521) (Life Technologies). A PCR reaction was performed for each pool and the samples were run on a $1 \%$ agarose gel to verify the absence of DNA contamination before the DNase reaction was inactivated. Pools that had no bands of PCR products from DNA amplification were used for gene transcription analysis.

RT-qPCR was performed for target genes (Table 1) associated with nickel resistance in other plant species. BLAST search for target genes was performed based on the Populus trichocarpa genome in the NCBI database. 
Table 1: Sequences of trembling aspen (Populus tremuloides) primers used for RT-qPCR

\begin{tabular}{lllll}
\hline Target & $\begin{array}{l}\text { Melting } \\
\text { temp }\left({ }^{\circ} \mathrm{C}\right)\end{array}$ & Primer & $\begin{array}{l}\text { Expected } \\
\text { amplicon (bp) }\end{array}$ & $\begin{array}{l}\text { PCR product } \\
\text { in cDNA (bp) }\end{array}$ \\
\hline NAS3 & F: 60.02 & F:AAAGTTGCGTTTGTGGGTTC & 232 & 232 \\
& R: 59.98 & R:CTGCCAAGAAGACGACATCA & & 292 \\
NRAMP4 & F: 59.96 & F: CCTTGTAAATGCAGGGCAAT & 292 & \\
Housekeeping & R: 60.02 & R: TGACTGCAGCACATTTAGCC & & 150 \\
$\alpha$-tubulin & F: 60.21 & F: GGCAAGCAGGGATTCAAGTA & 150 & \\
& R: 60.36 & R: GGCACATGTTTCCAGAACC & & \\
\hline
\end{tabular}

*Primers were designed by matching gene sequences to the Populus trichocarpa genome. When possible primers were designed to span the exon-exon border of the gene

Primers flanking the sequences of these genes were designed to span the exon-exon border of the gene, when possible. The OligoAnalyzer 3.1 program by IDT (https://www.idtdna.com/calc/analyzer) was used to check primer sequences for potential hairpins, self and hetero-dimers. Then, the cDNA synthesis was performed with the High Capacity cDNA Reverse Transcription Kit by Life Technologies. PCR was performed on cDNA and DNA. Reactions were run on a $1 \%$ agarose gel to verify the amplicon size. Primer pairs were used for RT-qPCR only if they showed a strong reproducible single band of the expected cDNA transcript size for the gene target. The RT-qPCR was performed according to the manufacturer's protocol using the Dynamo HS SYBR Green Kit (Life Technologies). Each reaction was run in triplicates using the MJ Research PTC-200 Thermal Cycler. The set program includes (1) initial denaturing at $95^{\circ} \mathrm{C}$ for $15 \mathrm{~min}$; (2) denaturing at $94^{\circ} \mathrm{C}$ for $30 \mathrm{sec}$; (3) $30 \mathrm{sec}$ at $55^{\circ} \mathrm{C}$ annealing; (4) elongation at $72^{\circ} \mathrm{C}$ for $30 \mathrm{sec}$; (5) read (6) repeat step 2-6 for 41 cycles; (7) final elongation at $72^{\circ} \mathrm{C}$ for $7 \mathrm{~min}$; (8) melting curve $72-95^{\circ} \mathrm{C}$, every $1{ }^{\circ} \mathrm{C}$, hold for $10 \mathrm{sec}$; and (9) final elongation at $72^{\circ} \mathrm{C}$ for $3 \mathrm{~min}$ as described in Kalubi et al. (2018). The RT-qPCR was performed two separate times per gene target and samples were loaded in triplicates. The result was six quantitation data points per bulked sample. Outliers among the triplicates were excluded in further analysis.

\section{Data Analysis}

The MJ Opticon Monitor 3.1 program by BioRad was used to analyze the data. The run data was exported to Excel. The $\mathrm{C}(\mathrm{t})$ Values were quantified using the equation for the standard curve and then normalized to the housekeeping gene $\alpha$-tubulin. SPSS 20 for Windows was used to determine statistical significance among means $(\mathrm{p}<0.05)$. The Shapiro Wilk test was performed to verify normal distribution of data. Data sets that did not meet requirements were log transformed to achieve normal distribution. Analysis of Variance (ANOVA) and Games-Howell Post-hoc Test were used to determine any significant differences among means for different treatments and controls.

\section{Results}

All the genotypes treated with different doses of nickel nitrate showed a high level of resistance to nickel toxicity. The transcription of NAS3 and NRAM4 genes in roots of $P$. tremuloides subject to these treatments was assessed using RT-qPCR. The primer pairs used to amplify the housekeeping and target genes are listed in Table 1.

A significant increase of NAS3 transcription was induced by the $400 \mathrm{mg} / \mathrm{kg}$ and $800 \mathrm{mg} / \mathrm{kg}$ of nickel nitrate doses compared to water. But no significant difference was observed between the $1,600 \mathrm{mg} / \mathrm{kg}$ dose and the water control (Fig. 1a). There was no significant difference in gene transcription when the $150 \mathrm{mg} / \mathrm{kg}$ dose of potassium nitrate was compared to water (Fig. 1b). Surprisingly, NAS3 transcription was significantly upregulated at the $400 \mathrm{mg} / \mathrm{kg}, 800 \mathrm{mg} / \mathrm{kg}$ and 1,600 $\mathrm{mg} / \mathrm{kg}$ dose of potassium nitrate with a $1.5 \mathrm{X}, 3 \mathrm{X}$ and $3 \mathrm{X}$ fold increase compared to water, respectively. Significant differences between nickel nitrate and potassium nitrate were observed at $150 \mathrm{mg} / \mathrm{kg}, 800$ $\mathrm{mg} / \mathrm{kg}$ and 1,600 mg/kg (Fig. 1c).

No significant difference in NRAMP 4 transcription was observed for any of the four nickel nitrate doses compared to water (Fig. 2a). On the other hand, there was an unexpected trend of increased NRAMP4 transcription when samples were treated with increasing concentrations of potassium nitrate (Fig. 2b). In fact, the $800 \mathrm{mg} / \mathrm{kg}$ dose and the $1,600 \mathrm{mg} / \mathrm{kg}$ dose of potassium nitrate resulted in a significant difference in this transcription compared to water control and the 150 $\mathrm{mg} / \mathrm{kg}$ dose. When nickel nitrate and potassium nitrate were compared, there was a significant upregulation of NRAMP 4 induced by $150 \mathrm{mg} / \mathrm{kg}$ of nickel nitrate compared to potassium nitrate used as control; and a significant downregulation for the $800 \mathrm{mg} / \mathrm{kg}$ and the $1,600 \mathrm{mg} / \mathrm{kg}$ (Fig. 2c) doses. 


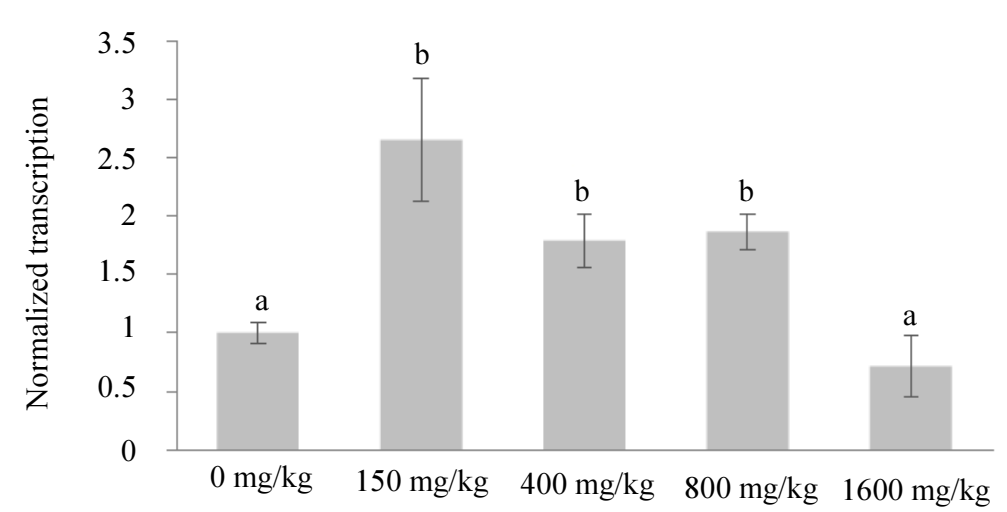

Nickel nitrate

Potassium nitrate

(a)

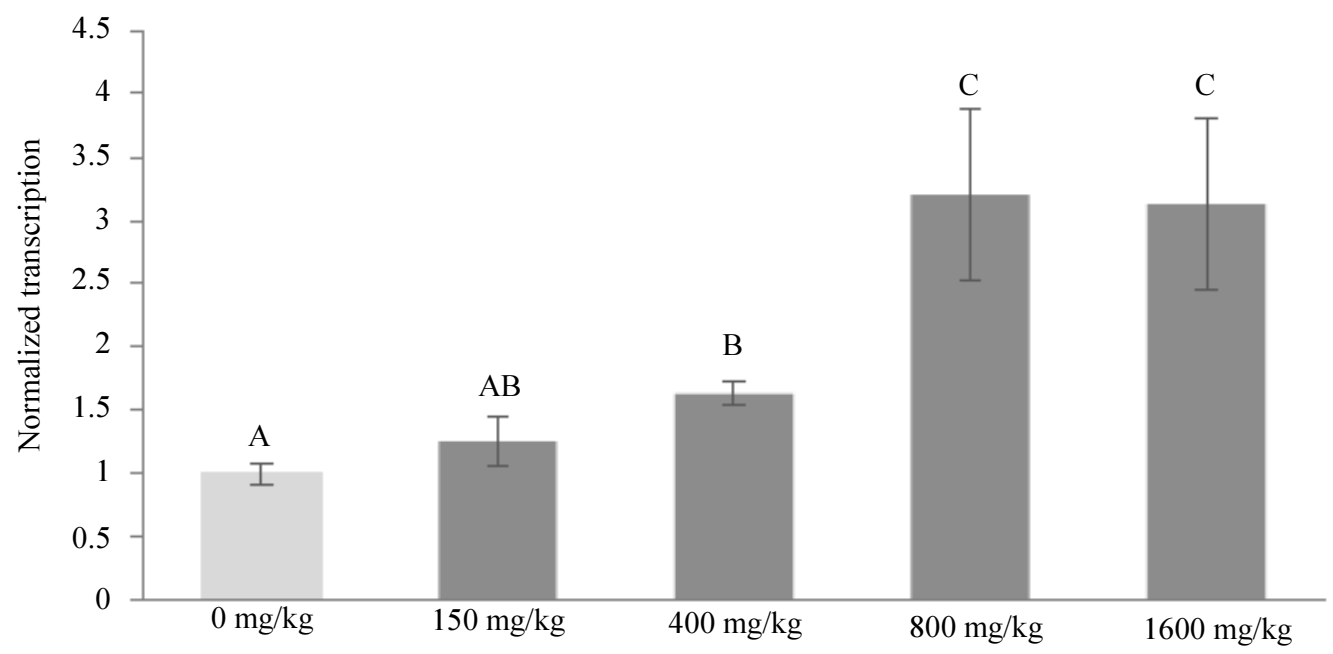

(b)

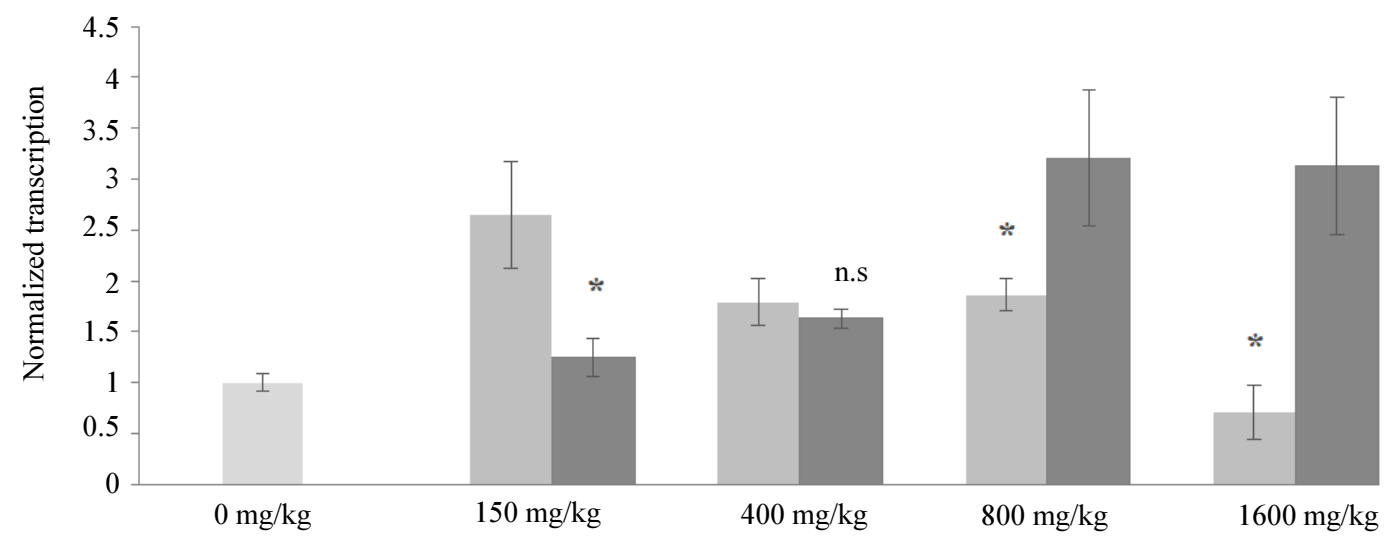

(c)

Fig. 1: NAS3 gene transcription in trembling aspen (Populus tremuloides) treated with different doses of (a) nickel nitrate and (b) potassium nitrate. The gene transcription was normalized to housekeeping gene $\alpha$-tubulin and water was used as the negative control. (c) Gene transcription of all the treatments combined. Bars with different lowercase indices represent significant differences $(p \leq 0.05)$ among the means of the nickel treatments with reference to water. Bars with different uppercase indices represent significant differences $(\mathrm{p} \leq 0.05)$ among the means of the nitrate treatments with reference to water. Significant differences $(p \leq 0.05)$ between a nickel concentration and its corresponding nitrate control dose are represented with an asterisk $(*)$. In Fig. 1c, n.s. means no significant difference was found between means 


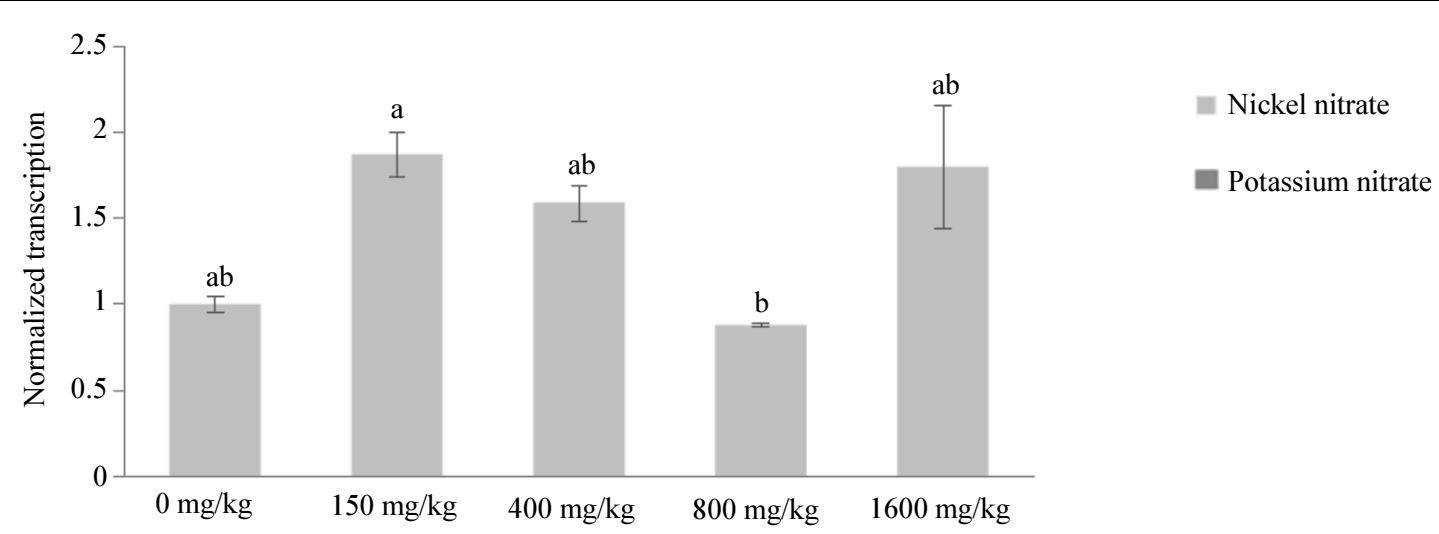

(a)

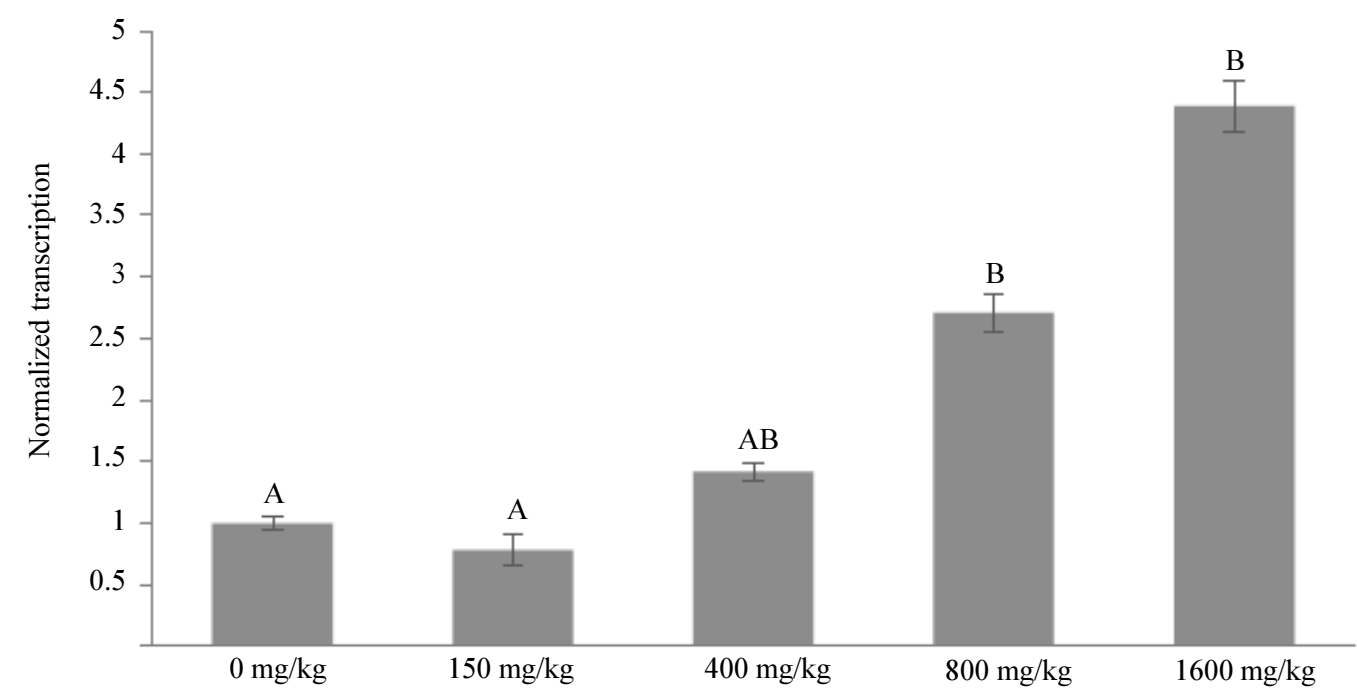

(b)

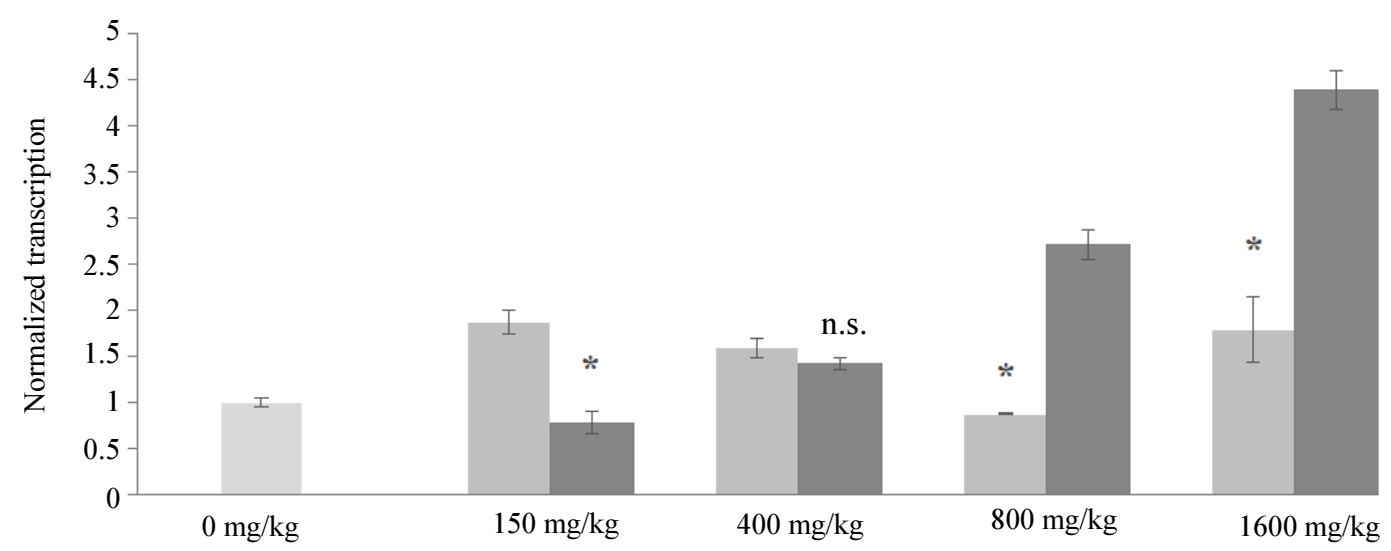

(c)

Fig. 2: NRAMP4 gene transcription in trembling aspen (Populus tremuloides) treated with different doses of (a) nickel nitrate and (b) potassium nitrate. The gene transcription was normalized to housekeeping gene $\alpha$-tubulin and water was used as the negative control. (c) Gene transcription of all the treatments combined. Bars with different lowercase indices represent significant differences $(p \leq 0.05)$ among the means of the nickel treatments with reference to water. Bars with different uppercase indices represent significant differences $(\mathrm{p} \leq 0.05)$ among the means of the nitrate treatments with reference to water. Significant differences $(p \leq 0.05)$ between a nickel concentration and its corresponding nitrate control dose are represented with an asterisk $(*)$. In Fig. 1c, n.s. means no significant difference was found between means 


\section{Discussion}

This study aimed to determine if genes associated with nickel tolerance in other model and non-model species are involved in the Populus tremuloides response to nickel and to assess if there is any nickel dosage effect. The two genes studied are involved in metal transport, which appears to be the main mechanism involved in metal resistance.

All the $P$. tremuloides genotypes treated with potassium nitrates showed no significant toxicity symptoms or damage. Unexpectedly, both $N A S 3$ and NRAMP4 transcription had a trend of upregulation with increasing concentration of potassium nitrate used as controls. This difference was most significant at the 800 $\mathrm{mg} / \mathrm{kg}$ dose for both genes. This highlights the importance of including control treatments when using metal salts to assess the toxicity of a specific metal.

The Nicotianamine Synthase (NAS) genes are important for the synthesis of the cross-metal chelator protein Nicotianamine (NA) which can bind numerous transition metals. Recently, $\mathrm{Ni}$ has been identified to have high binding affinity to NA, particularly in the Ni and $\mathrm{Zn}$ hyperaccumulator species $T$. caerulescens (Vacchina et al., 2003). The NAS3 gene was found to be overexpressed and high levels of NA were produced in $T$. caerulescens, Arabidopsis halleri, Noccaea caerulescens exposed to Ni (Vacchina et al., 2003; Deinlein et al., 2012; Visioli et al., 2014). It appears that an increase in nicotianamine contributes to metal tolerance in hyperaccumulator plants via metal chelation and facilitates metal translocation (Weber et al., 2004; Deinlein et al., 2012). In contrast, $N A S$ genes seem to play a role in metal homeostasis (i.e., $\mathrm{Fe}, \mathrm{Cu}, \mathrm{Zn}$ and $\mathrm{Mn})$ only in non-accumulating plants such as Arabidopsis thaliana (Curie et al., 2009).

It was expected that $N A S 3$ gene transcription would also be affected by $\mathrm{Ni}$ toxicity in $P$. tremuloides. But, our results show a trend of higher $N A S 3$ transcription in samples treated with both nickel nitrate and potassium nitrate. This suggests that nitrate rather than nickel affects the transcription of $N A S 3$ in our assays. This gene doesn't appear to play any role in $P$. tremuloides tolerance to nickel. The lower effect of the $1,600 \mathrm{mg} / \mathrm{kg}$ dose of nickel nitrate could be caused by an interaction of nickel with nitrate at high dose where nickel interferes with nitrate.

The NRAMP transporters gene family is conserved in many organisms including plants. This gene codes for NRAMP proteins that can bind and complex heavy metal ions for transport. The metal ions binding are dependent on the species and the protein. Some divalent cations that can be bound by NRAMP metal ion transporters include $\mathrm{Mn}^{2+}, \mathrm{Zn}^{2+}, \mathrm{Cu}^{2+}, \mathrm{Fe}^{2+}, \mathrm{Cd}^{2+}, \mathrm{Ni}^{2+}$ and $\mathrm{Co}^{2+}$ (Supek et al., 1997; Liu et al., 1997; Chen et al., 1999; Nevo and Nelson, 2004). Mizuno et al. (2005) were the first to identify the association NRAMP4 and $\mathrm{Ni}$ in a yeast study. They found an increase of NRAMP4 transcription in yeast cells exposed to nickel. In plants, Oomen et al. (2009) found that NRAMP3 and NRAMP4 are highly expressed in Thlaspi caerulescens which is a metal hyperaccumulator. The two genes can bind $\mathrm{Fe}, \mathrm{Mn}$ and $\mathrm{Cd}$ while $\mathrm{Zn}$ can be only bound by NRAMP4. Theriault et al. (2016a) further investigated NRAMP genes involved in Ni transport in white birch (Betula papyrifera). They found that plants that showed resistance to excess nickel may do so partially via the downregulation of genes associated with binding and transport activity like NRAMP1-2. In fact, the transcriptome analysis that they conducted associated the gene transcription of two NRAMP transporters with nickel resistance and accumulation in B. papyrifera. They found also a downregulation of five genes involved in metal transport including NRAMP1 and NRAMP2 in $\mathrm{Ni}$ resistant genotypes. We initially presumed that the transcription of NRAMP transporters may have a similar role in nickel resistance in P. tremuloides. The NRAMP 4 primers used in RT- qPCR confirmed the presence of this gene in $P$. tremuloides. But the results showed no significant differences in NRAMP4 transcription in any of the nickel treatments compared to water. Unexpectedly, high concentrations of potassium nitrates at the $800 \mathrm{mg} / \mathrm{kg}$ and $1,600 \mathrm{mg} / \mathrm{kg}$ dose did significantly increase NRAMP4 transcription in comparison with the water treatment. The direct comparison of nickel nitrate and potassium nitrate suggests that NRAMP4 transcription seems to be more affected by potassium than the nickel and these effects increase as the concentration increases. Similar studies that we have conducted demonstrated that potassium nitrate can induce a high level of transcription of 1aminocyclopropane-1-carboxylic acid (ACC) deaminase and NAS3 genes in leaves of Quercus rubra seedlings exposed to at low dose $(150 \mathrm{mg} / \mathrm{kg})$ of Ni. Our results also confirmed findings pf a field study on $P$. tremuloides and Acer rubrum indicating that the low level of bioavailable nickel in metal-contaminated soils $(<150 \mathrm{mg} / \mathrm{kg})$ cannot induce differential transcription of NAS3 and NRAMP4 (Kalubi et al., 2018).

\section{Conclusion}

The present study shows that nickel nitrate increases NAS3 transcription. This upregulation decreased as the salt concentration increased. Potassium nitrate also triggers an increase of the NAS3 transcription. But this gene upregulation increases as the salt concentration increased. On the other hand, NRAMP4 transcription was affected only by potassium. In fact, repeated assays revealed that potassium induced an upregulation of NRAMP4 that was dose - dependent. The use of nitrate without 
nickel should be required as additional controls in any study assessing effects of $\mathrm{Ni}$ using nickel nitrate salts.

\section{Acknowledgement}

This study was supported by the Natural Sciences and Engineering Council of Canada (NSERC). Thanks to Dr. Paul Michael for technical assistance.

\section{Authors Contributions}

Karolina M. Czajka: Conduct all the experiments, analyzed the data and contributed to the writing of the manuscript.

Kabwe Nkongolo: Designed the project activities, coordinated the experiments and wrote the manuscript.

\section{Conflict of Interest}

Karolina M. Czajka declares that she has no conflict of interest. Kabwe Nkongolo declares that he has no conflict of interest.

\section{Compliance with Ethical Standards}

This article does not contain any studies with human subjects or animals performed by any of the authors.

\section{References}

Chen, X.Z., J.B. Peng, A. Cohen, H. Nelson and N. Nelson et al., 1999. Yeast SMF1 mediates H(+)coupled iron uptake with concomitant uncoupled cation currents. J. Biol. Chem., 274: 35089-35094. DOI: $10.1074 / j b c .274 .49 .35089$

Curie, C., G. Cassin, D. Couch, F. Divol and K. Higuchi et al., 2009. Metal movement within the plant: Contribution of nicotianamine and yellow stripe 1like transporters. Ann. Bot., 103: 1-11. DOI: $10.1093 / \mathrm{aob} / \mathrm{mcn} 207$

Deinlein, U., M. Weber, H. Schmidt, S. Rensch and A. Trampczynska et al., 2012. Elevated nicotianamine levels in Arabidopsis halleri roots play a key role in zinc hyperaccumulation. Plant Cell, 24: 708-723. DOI: $10.1105 /$ tpc. 111.095000

Douchkov, D., C. Gryczka, U.W. Stephan, R. Hell and H. Bäumlein, 2005. Ectopic transcription of nicotianamine synthase genes results in improved iron accumulation and increased nickel tolerance in transgenic tobacco. Plant Cell Environ., 28: 365-374. DOI: $10.1111 /$ j.1365-3040.2005.01273.x

Freeman, J., M. Persans, K. Nieman, C. Albrecht and W. Peer et al., 2004. Increased glutathione biosynthesis plays a role in nickel tolerance in Thlaspi nickel hyperaccumulators. Plant Cell, 16: 2176-2191.

DOI: $10.1105 /$ tpc. 104.023036
Goyal, S.S. and R.C. Huffaker, 1984. Nitrogen toxicity in plants. Nitrogen in crop Production.

Kalubi, K.N, P. Michael and A. Omri, 2018. Analysis of gene transcription in red maple (Acer 13 rubrum) and trembling aspen (Populus tremuloides) populations from a mining region. Genes Genom. DOI: $10.1007 / \mathrm{s} 13258-018-0670-8$

Kalubi, K.N., M. Mehes-Smith and A. Omri, 2016. Comparative analysis of metal translocation in red maple (Acer rubrum) and trembling aspen (Populus tremuloides) populations from stressed ecosystems contaminated with metals. Chem. Ecol., 32: 312-323. DOI: $10.1080 / 02757540.2016 .1142978$

Lemaire, S., B. Guillon, P. Le Marechal, E. Keryer and M. Miginiac-Maslow et al., 2004. New thioredoxin targets in the unicellular photosynthetic eukaryote Chlamydomonas reinhardtii. Proc. Natl. Acad. Sci., 101: 7475-7480. DOI: $10.1073 /$ pnas.0402221101

Liu, J., H.J. Han, S.H. Kim, C.O. Lim and D.J. Yun et al., 2014. ZAT11, a zinc finger transcription factor, is a negative regulator of nickel ion tolerance in Arabidopsis. Plant Cell Rep., 33: 2015-2021. DOI: $10.1007 / \mathrm{s} 00299-014-1675-7$

Liu, X.F., F. Supek, N. Nelson and V.C. Culotta, 1997. Negative control of heavy metal uptake by the Saccharomyces cerevisiae BSD2 gene. J. Biol. Chem., 272: 11763-11769. DOI: $10.1074 /$ jbc.272.18.11763

Mari, S., D. Gendre, K. Pianelli, L. Ouerdane and R. Lobinski et al., 2006. Root-to-shoot long-distance circulation of nicotianamine and nicotianaminenickel chelates in the metal hyperaccumulator Thlaspi caerulescens. J. Exp. Bot., 57: 4111-4122. DOI: $10.1093 / \mathrm{jxb} / \mathrm{erl} 184$

Mehes-Smith, M., K.N. Nkongolo and E. Cholewa, 2013. Coping mechanisms of plant to metal contaminated soil. environmental change and sustainability. Dr. Steven Silvern (Ed.), InTech.

Merlot, S., L. Hannibal, S. Martins, L. Martinelli and H. Amir et al., 2014. The metal transporter PgIREG1 from the hyperaccumulator Psychotria gabriellae is a candidate gene for nickel tolerance and accumulation. J. Exp. Bot., 65: 1551-1564. DOI: $10.1093 / \mathrm{jxb} / \mathrm{eru} 025$

Mizuno, T., K. Usui, K. Horie, S. Nosaka and N. Mizuno et al., 2005. Cloning of three ZIP/Nramp transporter genes from a Ni hyperaccumulator plant Thlaspi japonicum and their Ni2+-transport abilities. Plant. Physiol. Biochem., 43: 793-801. DOI: $10.1016 /$ j.plaphy.2005.07.006 
Nevo, Y. and N. Nelson, 2004. The mutation F227I increases the coupling of metal ion transport in DCT1. J. Biol. Chem., 27951: 53056-53061. DOI: $10.1074 /$ jbc.M408398200

Oomen, R.J., K. Wu, F. Lelièvre, S. Blanchet and P. Richaud et al., 2009. Functional characterization of NRAMP3 and NRAMP4 from the metal hyperaccumulator Thlaspi caerulescens. New. Phytol., 181: 637-50. DOI: $10.1111 / \mathrm{j} .1469-8137.2008 .02694 . \mathrm{x}$

Parker, M.B., G.J. Gascho and T.P. Gaines, 1983. Chloride toxicity of soybeans grown on Atlantic coast flatwoods soils. Agron. J., 75: 439-443. DOI: 10.2134 /agronj 1983.00021962007500030005x

Schaaf, G., A. Honsbein, A.R. Meda, S. Kirchner and D. Wipf et al., 2006. AtIREG2 encodes a tonoplast transport protein involved in iron-dependent nickel detoxification in Arabidopsis thaliana roots. J. Biol. Chem., 281: 25532-25540. DOI: $10.1074 /$ jbc.M601062200

Stearns, J., S. Shah, B. Greenbeerg, D.G. Dixon and B.R. Glick, 2005. Tolerance of transgenic canola expressing 1-aminocyclopropane-1-carboxylic acid deaminase to growth inhibition by nickel. Plant Physiol. Biochem., 43: 701-708.

DOI: 10.1016/j.plaphy.2005.05.010

Supek, F., L. Supekova, H. Nelson and N. Nelson, 1997. Function of metal-ion homeostasis in the cell division cycle, mitochondrial protein processing, sensitivity to mycobacterial infection and brain function. J. Exp. Biol., 200: 321-330. PMID: 9050240

Theriault, G., P. Michael and K. Nkongolo, 2016a. Comprehensive transcriptome analysis of response to nickel stress in white birch (Betula papyrifera). PLoS ONE, 11: e0153762-e0153762.

DOI: 10.1371/journal.pone.0153762

Theriault, G., P. Michael and K. Nkongolo, $2016 \mathrm{~b}$. Decrypting the regulation and mechanism of nickel resistance in white birch (Betula papyrifera) using cross-species metal-resistance genes. Genes. Genom., 38: 341-350.

DOI: $10.1007 / \mathrm{s} 13258-016-0387-5$
Vacchina, V., S. Mari, P. Czernic, L. Marques and K. Pianelli et al., 2003. Speciation of nickel in a hyperaccumulating plant by high performance liquid chromotgraphy-inductively coupled plasma mass spectrometry and electrospray MS/MS assisted by cloning using yeast complementation. Anal. Chem., 75: 2740-2745. DOI: 10.1021/ac020704m

Visioli, G., M. Gulli and N. Marmiroli, 2014. Noccaea caerulescens populations adapted to grow in metalliferous and non-metalliferous soils: $\mathrm{Ni}$ tolernace, accumulation and transcription analysis of genes involved in metal homeostasis. Environ. Exper. Bot., 105: 10-17. DOI: $10.1016 /$ j.envexpbot.2014.04.001

Visioli, G., S. Vincenzi, M. Marmiroli and N. Marmiroli, 2012. Correlation between phenotype and proteome in the Ni hyperaccumulator Noccaea caerulescens subsp. caerulescens. Environ. Exp. Bot., 77: 156-164. DOI: 10.1016/j.envexpbot.2011.11.016

Weber, M., E. Harada, C. Vess, E. von RoepenackLahaye and S. Clemens, 2004. Comparative microarray analysis of Arabidopsis thaliana and Arabidopsis halleri roots identifies nicotianamine synthase, a ZIP transporter and other genes as potential metal hyperaccumulation factors. Plant. J., 37: 269-281

DOI: $10.1046 / j .1365-313 X .2003 .01960 . x$

Williams, L.E., J.K. Pittman, J.L. Hall, 2000. Emerging mechanisms for heavy metal transport in plants. Biochem. Biophys. Acta, 1465: 104-126.

Wintz, H., T. Fox, Y.Y. Wu, V. Feng and W. Chen et al., 2003. Transcription profiles of Arabidopsis thaliana in mineral deficiencies reveal novel transporters involved in metal homeostasis. J. Biol. Chem., 278: 47644-47653. DOI: 10.1074/jbc.M309338200 